Dept. of Vet. Medicine, Fac. of Agriculture and Vet. Medicine, Qassim Univ., P.O. Box 6622 Buraydah 51452, Saudi Arabia.

\title{
DIOXINS IN THE FOOD CHAIN REVIEW
}

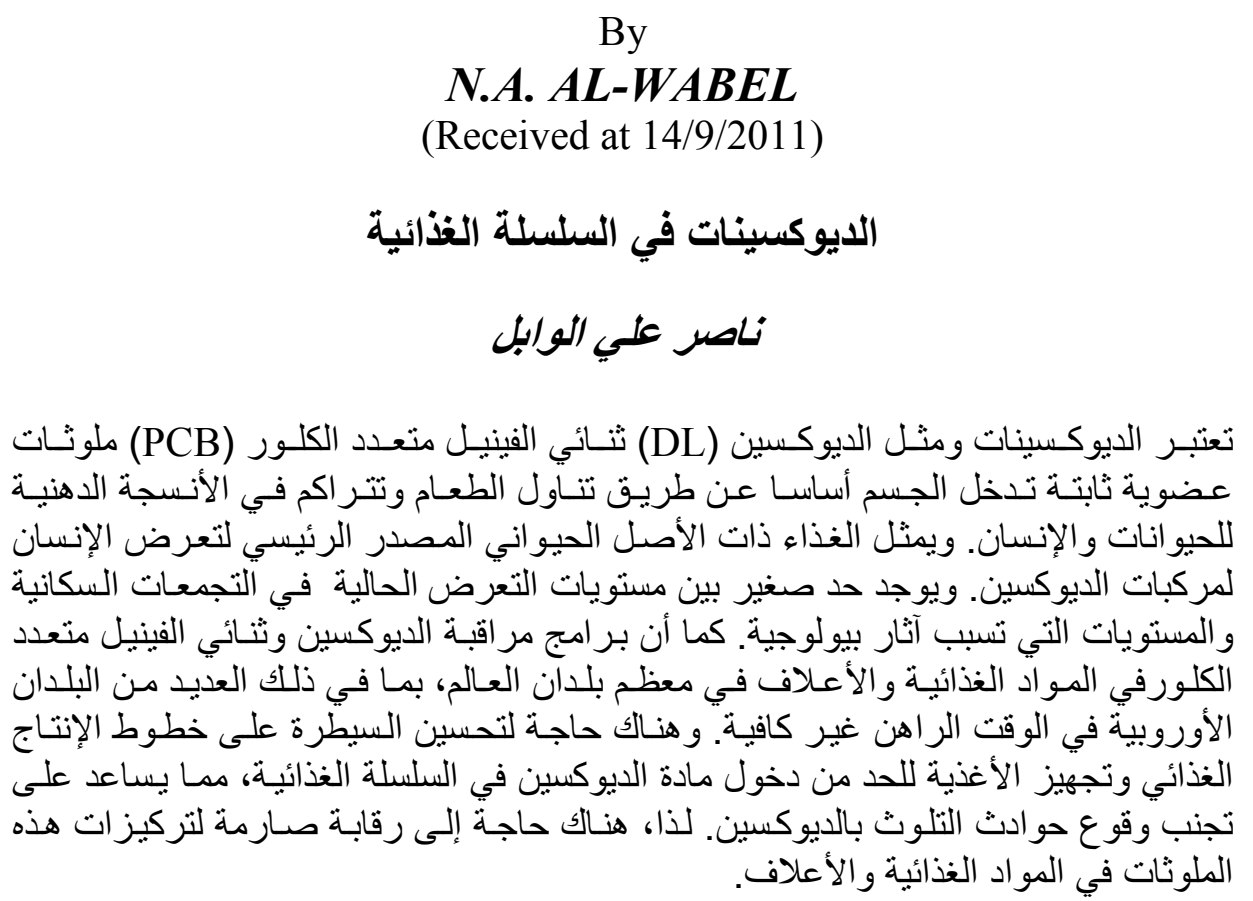

\section{SUMMARY}

Dioxins and dioxin-like (DL) polychlorinated biphenyls (PCB) are persistent organic pollutants that enter the body mainly by food intake and accumulate in the fat tissue of animals and humans. Foods of animal origin are the primary source of human exposure to dioxins. A small margin exists between current exposure levels in the human population and the levels causing biological effects. Dioxin and PCB monitoring programs for food and feeding stuff in most countries of the world, including many European Countries are currently inadequate. Better control of food production lines and food processing procedures is needed to minimize entry of dioxin to the food chain and will help to avoid dioxin contamination accidents. Therefore, stringent control of concentrations of these contaminants in food and feed is needed.

Key words: Dioxins, organic pollutants, food animals, food chain. 


\section{INTRODUCTION}

Polychlorinated dibenzo-p-dioxins (PCDDs), polychlorinated dibenzofurans (PCDFs) and certain dioxin-like polychlorinated biphenyls (dl-PCBs) are a family of chemically-related lipophilic compounds characterized by similar toxicity. Due to their properties they are universally distributed in the environment and classified as persistent organic pollutants (Esposito et al., 2009). Once they have been generated, PCDDs and PCDFs and other persistent organic pollutants can persist in soils and sediments and in waste repositories for periods extending from decades to centuries. The highest historical PCDD/F and PCB contamination burdens have arisen as a result of the production of chlorine and of chlorinated organic chemicals. In particular, the production of chlorinated pesticides, PCBs and the related contaminated waste streams are identified being responsible for historical releases of toxic equivalents (TEQs) at a scale of many tonnes. Along with such releases, major PCDD/F contaminated sites have been created through the application or improper disposal of contaminated pesticides, PCBs and other organochlorine chemicals, as well through the recycling of wastes and their attempted destruction. In some extreme examples, $\mathrm{PCDD} / \mathrm{F}$ contaminated sites have also resulted from thermal processes such as waste incinerators, secondary metal industries or from the recycling or deposition of specific waste (e.g. electronic waste or car shredder wastes), which often contain chlorinated or brominated organic chemicals (Weber et al., 2008).

Numerous factors may influence the concentration of dioxins in food animals such as the source of the dioxins (e.g. new emissions vs. recycling in the environment), aerial transport, degree of plant uptake, fate in the soil (half-life), animal uptake via feed and soil ingestion, bioavailability to the animal, and pharmacokinetics. Since ingestion of dioxins in contaminated vegetation and soil is considered the major pathway of exposure for food animals, different feeding practices such as confinement feeding, grazing, and percentage grain fed should have significant effects on actual concentrations of dioxins in animals. While these factors have been theoretically researched and modeled, little epidemiological or controlled research has been done to validate these hypotheses (Feil and Ellis, 1998).

Although the use of PCBs has been banned for several decades, 
they are still present in the environment and are occasionally mechanically released from sediment or transferred through the trophic chain. Field analyses have established correlations between exposure to PCBs and alterations in fish physiology including reproductive function. Experimental exposures have been mainly performed using dioxin-like PCBs or other congeners at very high concentrations. Exposure to PCBs mixtures mimicking some environmental situations, including mainly non dioxin-like congeners, can lead to a dramatic reduction in the number of offspring produced by a female over a lifetime. This is of great concern for wild species living under natural conditions (Daouk et al., 2011).

\section{Sources of dioxins in the food chain:}

Deposition of airborne dioxins onto plant and soil surfaces, and subsequent ingestion of this contaminated vegetation and soil by food animals, is considered the primary pathway by which dioxins enter the food chain. The levels produced in this way are considered background levels. Fish become contaminated due to airborne dioxin deposition into the water and also from contaminated soil or industrial waste washed into rivers and lakes, leading to high sediment concentrations. Inhalation and water pathways are not considered significant sources of exposure for terrestrial animals. Contamination above background levels can occur if food animals are fed products which are adulterated, either by natural or unnatural means, with high concentrations of dioxins. For terrestrial animals, the intake of vegetation or roughages is considered the most important dioxin exposure factor (Fries, 1995a). Also, ingestion of contaminated grains and forage should account for $70 \%$ and $79 \%$, while ingestion of contaminated soil should account for $29 \%$ and $20 \%$ of the total daily intake of dioxins in beef and dairy cattle, respectively (Travis and Hattemer-Frey, 1991).

The consumption of grass/hay/silage/grain explained over $90 \%$ of dioxin concentrations in beef. As well as, soil ingestion by beef cattle only explained about $10 \%$ of final dioxin concentrations in beef. Soil ingestion is also a possible pathway for contamination in free range poultry and swine raised on pasture or dirt lots (Lorber et al., 1994). Furthermore, soil ingestion by livestock is also a significant source of exposure to dioxins. The use of pasture for ruminants is a factor in the soil pathway, since animals on pasture ingest contaminated soil along with the vegetation. The amount of soil ingested is related inversely to the availability of forage when pasture is the sole source of feed. Soil 
ingestion is reduced when animals on pasture are given supplemental feed. Cattle confined to dirt lots also consume small amounts of soil that can lead to meat residues (Fries, 1995b).

Livestock may also be exposed to dioxins from pentachlorophenol (PCP) treated wood on production facilities. PCP treated wood was used extensively in animal housing and confinement facilities until its use was restricted by the EPA in 1980. The frequent use of PCP treated wood, the propensity of animals to lick or chew wood, and the compatibility of congener profiles suggest that PCP treated wood may be an important source of residues in animal products in the U.S. (Fries et al., 1996). Moreover, the dioxin congener (chemical variations) patterns in beef fat samples were similar, after adjusting for differential congener absorption by animals, to the congener patterns identified in PCP treated wood samples from the facilities housing the animals (Feil and Larsen, 1999).

Lovett et al. (1998) conducted a survey of dioxins in eggs and poultry meat from a site close to a chemical waste incinerator, and several other urban and rural sites in the United Kingdom. Dioxin concentrations in poultry produced from the site closest to the incinerator were higher than concentrations in poultry produced from other sites. There were also variations in the chemical composition of the dioxins associated with their geographic origin. Also, Ramos et al. (1997) compared dioxin concentrations in milk samples from dairy farms in Spain located in rural areas without specific dioxin sources (control farms), to milk from farms in the vicinity of potential dioxin emission sources (case farms), and to pasteurized milk from retail outlets. The milk samples from control farms had only slightly lower concentrations of dioxins than the milk produced near emissions sources. However, the highest concentrations of dioxins were found in samples produced near a waste incinerator and a chemical plant. The lowest levels were found in pasteurized milk samples purchased from retail outlets in Spain and in milk from one of the control farms.

Another potential source of dioxin contamination of the vegetation and soil consumed by animals is the application of sewage sludge to pasture or crops intended for animal consumption. Sewage sludge is contaminated with a complex mixture of organic compounds, including dioxins (Engwall and Hjelm, 2000). In a study of the impact of using sewage sludge to restore degraded land, Molina et al. (2000) found that sewage sludge increased the dioxin concentration in the soils and 
that the contamination persisted through the one year study period. However, Engwall and Hjelm, (2000) found carrots grown in soil that had sewage sludge applied to it had higher concentrations of dioxins compared to controls; however, concentrations in the parts of the plant which grow above ground were generally low.

Recently, in Italy a polychlorinated biphenyls (PCB) production plant polluted soil and forage of the surrounding fields and caused a significant contamination of meat and milk of the cattle fed with local forage. This in turn induced elevated blood levels of PCDDs, PCDFs and PCBs in the consumers. The contamination levels and profiles measured in the perirenal fat, in the liver and in the milk of the overall 28 contaminated bovines (Turrio-Baldassarri et al., 2009).

Therefore, locating livestock and poultry operations and cultivating crops used for animal feed away from sources of dioxin emissions may be important in controlling dioxin concentrations in food animals.

\section{Foods contaminated by dioxins:}

Dairy products, meat and poultry, eggs, fish, and animal fats have the highest dioxin concentrations, while green vegetables, fruits and grains are the types of foods with the lowest dioxin concentrations (Eduljee and Gair, 1996). In The U.S. the pooled sample of fresh water fish had the highest level of dioxins (1.43 TEQ), followed by butter (1.07 TEQ), hotdog/bologna (0.54 TEQ), ocean fish (0.47 TEQ), cheese (0.40 TEQ), beef (0.38 TEQ), eggs (0.34 TEQ), ice cream (0.33 TEQ), chicken (0.32 TEQ), pork (0.32 TEQ), milk (0.12 TEQ), and vegetables, fruits, grains and legumes (0.07 TEQ) (Schecter et al., 1997). In The Netherlands, dairy products contributed about $50 \%$ of the dietary intake of a group of preschool children of dioxins and related compounds, while meat/meat products and processed foods contributed about $20 \%$ and 25\%, respectively (Patandin et al., 1999).

A stock of recycled fat that had been delivered to a manufacturer of animal feed, was determined to be the source of the dioxin toxicity. Almost 3,000 Belgian poultry, beef, and pig farms may have used the contaminated feed, along with some farms in France, the Netherlands, and Spain. Belgium implemented a large-scale food monitoring program to determine the extent of contamination, and found that poultry and poultry products were affected to a greater extent than swine (Bernard et al., 1999).

In Belgium, Pussemier et al. (2004) revealed high levels of 
$\mathrm{PCDD} / \mathrm{F}$ in the home-produced eggs (average $=9.9 \mathrm{pg}$ WHO-TEQ per $\mathrm{g}$ of fat; $n=15$ ). An evaluation of the available results has been carried out by the Scientific Committee of the Belgian Federal Agency for the Safety of the Food Chain. There were not enough indications allowing a causal link to be established between high dioxin levels in eggs and soil contamination and, on the other hand, it was assumed that other factors such as feeding habits, physiological state and egg laying rhythm of the hens could not be ruled out as potential causes of aggravation. A quick risk assessment led to the conclusion that the impact of this contamination is highly relevant for the consumer's health due to the important contribution of such home-produced eggs in the estimations of total body burden. While, In Poland the majority of contaminants (toxic metals--mercury, cadmium, lead, arsenic; dioxin/furans--PCDDFs; dioxin-like PCB--dl-PCBs; seven congeners of polybrominated diphenyl ethers--PBDEs; organochlorine pesticides--SigmaDDT, HCB, SigmaHCH and marker polychlorinated biphenyls--PCB(7)) were present in low levels in smoked fish, salted fish, and marinated fish. The possible threats, particularly in the case of pregnant/nursing women and young children, can pose the levels of dioxin/furans $(\mathrm{PCDD} / \mathrm{Fs})$ and dioxin-like (dl-PCBs) in smoked Baltic salmon and smoked sprat, elevated in a relation to particular requirements concerning the content of sum of PCDD/Fs and dl-PCBs in fish (8pg WHO-TEQg(-1)) (Usydus et al., 2009).

Biota sediment accumulation factors (BSAFs) for polychlorinated biphenyls (total PCB) and polychlorinated dioxinsfurans $(\mathrm{PCDD} / \mathrm{Fs})$ in the Canadian Great Lakes was calculated using measured lake sediment and fish tissue concentrations in 4 fish species, namely, lake trout, whitefish, rainbow trout, and channel catfish. The PCDD/Fs fca-SQTs ranged from 6 to $128 \mathrm{pg}$ toxic equivalents (TEQ)/g dry weight $(\mathrm{dw})$ and were above the Canadian Council of the Ministers of the Environment (CCME) threshold effect level (TEL) of $0.85 \mathrm{pg}$ $\mathrm{TEQ} / \mathrm{g}$ dw. In contrast, the total PCB fca-SQTs ranged from 1 to $60 \mathrm{ng} / \mathrm{g}$ $\mathrm{dw}$ and were generally below the CCME's TEL of $34.1 \mathrm{ng} / \mathrm{g}$ and OMOE's lowest effect level (LEL) of $70 \mathrm{ng} / \mathrm{g}$; however, they were consistent with the OMOE's no effect level (NEL) of $10 \mathrm{ng} / \mathrm{g}$ (Bhavsar et al., 2010). Most fish have at least some degree of chemical contamination with methylmercury, (which binds to muscle) and/or with persistent organic pollutants such as dioxins, polychlorinated biphenyls, polybrominated diphenyl ethers, chlorinated pesticides (which concentrate in fish fat). These chemicals have adverse effects on nervous 
system function, modulate the immune system, and are associated with elevations in risk of cardiovascular disease (Bushkin-Bedient and Carpenter, 2010).

High levels of dioxins (PCDD/Fs) in pork were discovered in France and the Netherlands at the end of 2008. The contamination was rapidly traced back to a feed stock in the Republic of Ireland (RoI). Burning oil, used for the drying of bakery waste, appeared to be contaminated with PCBs. The congener pattern clearly pointed to PCBoil as a source, but the ratio between the non-dioxin-like indicator PCBs (PCBs 28, 52, 101, 138, 152 and 180) and PCDD/Fs was much lower than observed during the Belgian incident, thereby limiting the suitability of indicator PCBs as a marker for the presence of dioxins and dioxin-like PCBs (Heres et al., 2010). The bioaccumulation of polychlorodibenzodioxins (PCDD) and polychlorodibenzofurans (PCDF), dioxin-like polychlorobiphenyls (DL-PCB), and 13 selected polybromodiphenylethers (PBDE) was assessed in autochthonous pigs reared in the Nebrodi Park of Sicily (Italy). The highest concentrations of PCDD + PCDF and DL-PCB were detected in the fat $(0.45$ and 0.35 pg World Health Organization toxicity equivalents [WHO-TE] per g of fat base [FB], respectively) and livers (12.7 and $3.28 \mathrm{pg}$ WHO-TE per $\mathrm{g}$ FB) of the wild group, whereas the free-ranging group showed the lowest levels (0.05 and 0.03 pg WHO-TE per g FB in fat and 0.78 and $0.27 \mathrm{pg}$ WHO-TE per $\mathrm{g}$ FB in livers). The sum of PBDE congeners was highest in wild pigs $(0.52 \mathrm{ng} / \mathrm{g}$ FB in fat and $5.64 \mathrm{ng} / \mathrm{g}$ FB in livers) and lowest in the farmed group $(0.14 \mathrm{ng} / \mathrm{g} \mathrm{FB}$ in fat and $0.28 \mathrm{ng} / \mathrm{g} \mathrm{FB}$ in livers). The contamination levels in fat and livers of outdoor pigs had mean concentration values lower than those levels reported for intensively indoor-farmed animals. In wild pigs, bioaccumulation was associated with their free grazing in areas characterized by bush fires (Brambilla et al., 2011).

\section{Human exposure to dioxins:}

The most important route for human exposure to PCDDs, PCDFs and (dioxin-like) PCBs is food consumption contributing over $90 \%$ of total exposure, with products of animal origin and fish making the greatest contribution to this exposure (Liem et al. 2000). The general population's exposure to dioxins and PCBs is still in the same range (1-4 $\mathrm{pg}$ WHO-TEQ/kg body weight and day) as the recently revised WHO tolerable daily intake (TDI). There is concern that short-term high level exposure to dioxins, furans, and PCB may cause biological effects on the 
human fetal development and further research is required. Further actions to control sources building on considerable advances already made in many countries may need to be supplemented by measures to prevent direct contamination of feeding stuff or food to reduce general population exposure further (Büchert et al., 2001). Human health risk assessments for dioxins and dioxin-like PCBs (with the exception of the one by US - Environmental Protection Agency (EPA) recommend health based exposure limits within the range of 1-4 pg WHO-TEQ $/ \mathrm{kg}$ bw per day. As all humans are exposed to measurable levels of dioxins and related substances, the determination of the tolerated daily intake (TDI) is a very significant decision and may influence limit values guiding risk reduction measures and target levels. A higher TDI lowers the level of protection for humans. So the only remaining way to lower the dioxin uptake is to drastically reduce the background exposure of the general population (Gies et al., 2007).

\section{Human dietary intake of dioxins:}

A person's intake of dioxins through the diet depends on the relative intake of foods with high or low levels of contamination and the quantity consumed (Schecter et al., 1997). The dietary intake of PCDDs and PCDFs by the general population of industrialized countries is on average 1-3 picograms of (i)-TEQ per kilogram body weight per day. So, the exposure of the general human population to PCDDs, PCDFs and (dioxin-like) PCBs should be taken into consideration for a risk assessment of these exposures. If the contribution of dioxin-like PCBs are also considered, the daily TEQ intake can be a factor of two to three higher. Special consumption habits and consumption of highly contaminated foodstuffs may lead to lower and higher TEQ intakes. In general, TEQ intake increases during childhood and stabilizes in adults of about 20 years of age (Liem et al., 2000). The daily intake of dioxins per $\mathrm{kg}$ of body weight for a $50 \mathrm{~kg}$ average adult body was $2.18 \mathrm{pg}$ $\mathrm{TEQ} / \mathrm{kg} /$ day in $1999,1.87 \mathrm{pg} \mathrm{TEQ} / \mathrm{kg} /$ day in $2000,1.25 \mathrm{pg} \mathrm{TEQ} / \mathrm{kg} /$ day in $2001,1.60 \mathrm{pg} \mathrm{TEQ} / \mathrm{kg} / \mathrm{day}$ in 2002 and 2003 and $1.55 \mathrm{pg} \mathrm{TEQ} / \mathrm{kg} / \mathrm{day}$ in 2004, respectively. These amounts were less than the tolerable daily intake (TDI) of $4 \mathrm{pg}$ TEQ $/ \mathrm{kg} /$ day for dioxins established in Japan. The dioxins taken daily through fish and shellfish (group 10) accounted for more than $50 \%$ of sum WHO-TEQs. In addition, more than $90 \%$ of the daily intake of dioxins was taken through fish and shellfish, meat and eggs, milk and dairy products. The ratio of dioxin-like PCBs in the daily intake of dioxins was increasing yearly because the reduction rate of 
dioxin-like PCBs was lower than that of PCDDs and PCDFs in foods (Sasamoto et al., 2006). From most of studies carried out to evaluate human dietary intake, milk and dairy products result as a major contributors of $\mathrm{PCDD} / \mathrm{Fs}$ uptake. Of course the main source of milk contamination is animal feeds. Lactating ruminants, cows included, transfer these compounds to the food chain by ingestion of contaminated vegetables or soil. Their resistance to degradation and a high lipophilicity means that PCDD/Fs and dl-PCBs may be accumulated into fat tissues from which they are transferred to milk during lactation period (Esposito et al., 2009). In Japan, the daily intake of dioxin-TEQ (toxic equivalent) from food per adult person was estimated respectively as $104.24 \mathrm{pg} \mathrm{TEQ} /$ person/day in 2000, $72.73 \mathrm{pg} \mathrm{TEQ} /$ person/day in 2001, and $87.28 \mathrm{pg} \mathrm{TEQ/person/day} \mathrm{in} \mathrm{2002,} \mathrm{corresponding} \mathrm{to} \mathrm{2.08,}$ 1.45 , and $1.74 \mathrm{pg} T E Q / \mathrm{kg}$ body weight $(\mathrm{bw}) /$ day for an adult weighing $50 \mathrm{~kg}$. The highest contribution ratio to the total intake of dioxin-TEQ was from fish and shellfish in each year, accounting for $77-92 \%$. The next highest contributor was meat and eggs (Nakatani et al., 2011).

\section{CONCLUSION}

Dioxin and related chemical compounds are toxic industrial pollutants which are ubiquitous and persistent in the environment, and which accumulate in the fat tissue of animals and humans. Foods of animal origin are the primary source of human exposure to dioxins. Terrestrial food animals are thought to accumulate background levels of dioxin primarily through ingestion of contaminated vegetation and soil.

\section{REFERENCES}

Bernard, A.; Hermans, C. and Broeckaert, F. (1999): Food contamination by PCBs and dioxins. Nature. Sept. 16, 401: 231-232.

Bhavsar, SP.; Gewurtz, SB.; Helm, PA.; Labencki, TL.; Marvin, CH.; Fletcher, R.; Hayton, A.; Reiner, EJ. and Boyd, D. (2010): Estimating sediment quality thresholds to prevent restrictions on fish consumption: Application to polychlorinated biphenyls and dioxins-furans in the Canadian Great Lakes. Integr Environ Assess Manag. 2010 Oct; 6(4): 641-52.

Brambilla, G.; De Filippis, SP.; Iamiceli, AL.; Iacovella, N.; Abate, V.; 
Aronica, V.; Di Marco, V. and di Domenico, A. (2011): Bioaccumulation of dioxin-like substances and selected brominated flame retardant congeners in the fat and livers of black pigs farmed within the Nebrodi Regional Park of Sicily. J Food Prot. 2011 Feb; 74(2): 261-9.

Büchert, A.; Cederberg, T.; Dyke, P.; Fiedler, H.; Fürst, P.; Hanberg, A.; Hosseinpour, J.; Hutzinger, O.; Kuenen, JG.; Malisch, R.; Needham, LL.; Olie, K.; Päpke, O.; Rivera Aranda, J.; Thanner, G.; Umlauf, G.; Vartiainen, T. and van Holst, C. (2001): Dioxin contamination in food. Bayreuth, Germany, from September 28 to October 1, 2000. Environ Sci Pollut Res Int. 2001; 8(2): 84-8.

Bushkin-Bedient, S. and Carpenter, DO. (2010): Benefits versus risks associated with consumption of fish and other seafood. Rev Environ Health. 2010 Jul-Sep, 25(3): 161-91.

Daouk, T.; Larcher, T.; Roupsard, F.; Lyphout, L.; Rigaud, C.; Ledevin, M.; Loizeau, V. and Cousin, X. (2011): Long-term food-exposure of zebrafish to PCB mixtures mimicking some environmental situations induces ovary pathology and impairs reproduction ability. Aquat Toxicol. 2011 Jun 28; 105(3-4): 270-278.

Eduljee, GH. and Gair, AJ. (1996): Validation of a methodology for modeling PCDD and PCDF intake via the foodchain. Science of the Total Environment. 183(3):211-29.

Engwall, M. and Hjelm, K. (2000): Uptake of dioxin-like compounds from sewage sludge into various plant species--assessment of levels using a sensitive bioassay. Chemosphere. 40(9-11): 1189-95.

Esposito, M.; Cavallo, S.; Serpe, FP.; D'Ambrosio, R.; Gallo, P.; Colarusso, G.; Pellicanò, R.; Baldi, L.; Guarino, A. and Serpe, L. (2009): Levels and congener profiles of polychlorinated dibenzo-p-dioxins, polychlorinated dibenzofurans and dioxinlike polychlorinated biphenyls in cow's milk collected in Campania, Italy. Chemosphere. 2009 Nov; 77(9): 1212-6.

Feil, VJ. and Ellis, RL. (1998): The USDA perspective on dioxin concentrations in dairy and beef. Journal of Animal Science. 76(1): 152-9.

Feil, VJ. and Larsen, GL. (1999): Dioxins in food from animal sources. American Chemical Society Meeting, March 1999, Anaheim CA. Abstract and Proceedings.

Fries, GF. (1995a): A review of the significance of animal food 
products as potential pathways of human exposures to dioxins. Journal of Animal Science. 73(6): 1629-50.

Fries, GF. (1995b): Transport of organic environmental contaminants to animal products. Reviews of Environmental Contamination and Toxicology. 141: 71-109.

Fries, GF.; Feil, VJ. and Davison, KL. (1996): The significance of pentachlorophenol-treated wood as a source of dioxin residues in United States beef. Organohalogen Compounds. 28: 156-159.

Gies, A.; Neumeier, G.; Rappolder, M. and Konietzka, R. (2007): Risk assessment of dioxins and dioxins and dioxin-like PCBs in foodcomments by the German Federal Environmental Agency. Chemosphere. Apr.; 67 (9): S344-9.

Heres, L.; Hoogenboom, R.; Herbes, R.; Traag, W. and Urlings, B. (2010): Tracing and analytical results of the dioxin contamination incident in 2008 originating from the Republic of Ireland. Food Addit Contam Part A Chem Anal Control Expo Risk Assess. 2010 Dec; 27(12): 1733-44.

Liem, AK.; Fürst, P. and Rappe, C. (2000): Exposure of populations to dioxins and related compounds. Food Addit Contam. 2000 Apr; 17(4): 241-59.

Lorber, M.; Cleverly, D. and Schaum, J. (1994): Development and validation of an air-to-beef food chain model for dioxin-like compounds. The Science of the Total Environment. 156:39-65.

Lovett, AA.; Foxall, CD.; Creaser, CS. and Chewe, D. (1998): PCB and $\mathrm{PCDD} / \mathrm{DF}$ concentrations in egg and poultry meat samples from known urban and rural locations in Wales and England. Chemosphere. 37 (9-12): 1671-85.

Molina, L.; Diaz-Ferrero, J. and Coll, M. et al. (2000): Study of evolution of $\mathrm{PCDD} / \mathrm{F}$ in sewage sludge-amended soils for land restoration purposes. Chemosphere. 40(9-11): 1173-8.

Nakatani, T.; Yamamoto, A. and Ogaki, S. (2011): A survey of dietary intake of polychlorinated dibenzo-p-dioxins, polychlorinated dibenzofurans, and dioxin-like coplanar polychlorinated biphenyls from food during 2000-2002 in Osaka City, Japan. Arch Environ Contam Toxicol. 2011 Apr; 60(3): 543-55.

Patandin, S.; Dagnelie, PC. and Mulder, PG. (1999): Dietary exposure to polychlorinated biphenyls and dioxins from infancy until adulthood: A comparison between breast-feeding, toddler, and long-term exposure. Environmental Health Perspectives. 107(1): 
45-51.

Pussemier, L.; Mohimont, L.; Huyghebaert, A. and Goeyens, L. (2004): Enhanced levels of dioxins in eggs from free range hens; a fast evaluation approach. Talanta. 2004 Aug 8; 63(5): 1273-6.

Ramos, L.; Eljarrat, E. and Hernandez, LM. (1997): Levels of PCDDs and PCDFs in farm cow's milk located near potential contaminant sources in Asturias (Spain). Comparison with levels found in control, rural farms and commercial pasteurized cow's milks. Chemosphere. 35(10): 2167-79.

Sasamoto, T.; Ushio, F.; Kikutani, N.; Saitoh, Y.; Yamaki, Y.; Hashimoto, T.; Horii, S.; Nakagawa, J. and Ibe, A. (2006): Estimation of 1999-2004 dietary daily intake of PCDDs, PCDFs and dioxin-like PCBs by a total diet study in metropolitan Tokyo, Japan. Chemosphere. 2006 Jul; 64(4): 634-41.

Schecter, A.; Cramer, P. and Boggess, K. (1997): Levels of dioxins, dibenzofurans, PCB and DDE congeners in pooled food samples collected in 1995 at supermarkets across the United States. Chemosphere. 34(5-7): 1437-47.

Travis, CC. and Hattemer-Frey, HA. (1991): Human exposure to dioxin. The Science of the Total Environment. 104: 97-127.

Turrio-Baldassarri, L.; Alivernini, S.; Carasi, S.; Casella, M.; Fuselli, S.; Iacovella, N.; Iamiceli, AL.; La Rocca, C.; Scarcella, C. and, Battistelli, CL. (2009): PCB, PCDD and PCDF contamination of food of animal origin as the effect of soil pollution and the cause of human exposure in Brescia. Chemosphere. 2009 Jun;76(2): 278-85.

Usydus, Z.; Szlinder-Richert, J.; Polak-Juszczak, L.; Komar, K.; Adamczyk, M.; Malesa-Ciecwierz, M. and Ruczynska, W. (2009): Fish products available in Polish market--assessment of the nutritive value and human exposure to dioxins and other contaminants. Chemosphere. 2009 Mar; 74(11): 1420-8.

Weber, R.; Gaus, C.; Tysklind, M.; Johnston, P.; Forter, M.; Hollert, H.; Heinisch, E.; Holoubek, I.; Lloyd-Smith, M.; Masunaga, S.; Moccarelli, P.; Santillo, D.; Seike, N.; Symons, R.; Torres, JP.; Verta, M.; Varbelow, G.; Vijgen, J.; Watson, A.; Costner, P.; Woelz, J.; Wycisk, P. and Zennegg, M. (2008): Dioxin- and POPcontaminated sites--contemporary and future relevance and challenges: overview on background, aims and scope of the series. Environ Sci. Pollut Res. Int. 2008 Jul; 15(5): 363-93. 
Assiut Vet. Med. J. Vol. 57 No. 131 October 2011

ir 